\title{
FAKTOR-FAKTOR EKSTERNAL DAN INTERNAL DALAM EFEKTIVITAS PELAKSANAAN PROYEK PEMBANGUNAN HOTEL ASHLEY SABANG
}

\author{
Eka Wulandari ${ }^{1}$ dan Wahyu Indra Sakti Saidi ${ }^{2}$
}

\author{
1Prodi Teknik Sipil, Universitas Tarumanagara, Jl. Letjen S. Parman No 1, Jakarta, 11440 \\ Email korespondensi: ekaecha.wulandari@gmail.com \\ 2Prodi Teknik Sipil, Universitas Tarumanagara, Jl. Letjen S. Parman No 1, Jakarta, 11440 \\ Email : wahyusaidi@gmail.com
}

\begin{abstract}
ABSTRAK
Salah satu upaya pemerintah pusat dalam mengatasi keterbatasan lahan di wilayah DKI Jakarta yang semakin sempit untuk hunian bagi wisatawan, pengusaha, pebisnis baik warga luar Jakarta maupun wisatawan mancanegara, maka pemerintah memberikan izin kepada setiap pengusaha untuk mendirikan hunian vertikal atau hotel. Pada setiap proyek konstruksi pembangunan hotel harus tetap memperhatikan faktor-faktor eksternal dan internal yang menjadi penentu proyek tersebut efektivitas atau tidak dalam pelaksanaannya. Penelitian ini bertujuan untuk mengetahui faktor-faktor eksternal dan faktor-faktor internal penentu efektivitas pelaksanaan proyek pembangunan Hotel Ashley Sabang. Yang menjadi sampel penelitian dalam tesis ini adalah kontraktor struktur dan arsitektur, kontraktor mekanikal, elektrikal dan plumbing, dan kontraktor interior di proyek Hotel Ashley Sabang sebagai objek penelitian, dengan metode sampling purposive. Metode analisis yang digunakan adalah uji validitas, uji reliabilitas, uji normalitas data, analisis karakteristik responden dan analisis relative importance index (RII). Hasil analisis menunjukkan bahwa terdapat faktor eksternal penentu efektivitas pelaksanaan proyek yang meliputi, penggunaan internet untuk mencari sumber informasi, pemakaian media e-mail sebagai alat komunikasi surat menyurat dan selalu menyelesaikan masalah dengan masyarakat jika ada perselisihan. Sedangkan faktor internal penentu efektivitas pelaksanaan proyek yaitu, komitmen yang sudah dibuat antara owner dan kontraktor tepat waktu, membuat hasil kerja lebih berkualitas dan produktivitas dan mampu bersama-sama memecahkan konflik di proyek.
\end{abstract}

Kata Kunci: Proyek Konstruksi, Faktor Eksternal, Faktor Internal, Efektivitas,

\begin{abstract}
One of the government effort in overcoming the land limitation in the DKI Jakarta which is it become limited for tourists, investor and businessman who come from Jakarta or international, so for that reason the government allow all the investor to build the hotel. In every hotel project construction, the investor have to give attention for the external and internal factors which determines the effectiveness of the project. The aim of this research is to determine the external and internal factors of the implementation effectiveness for the Ashley Sabang Hotel development project. The research samples in this thesis are structural and architectural contractors, mechanical electrical and plumbing contractors, and interior contractors at the Ashley Sabang Hotel as research objects, using purposive sampling method. The analytical method used is validity test, reliability test, data normality test, analysis of respondent characteristics and analysis of relative importance index (RII). The results of the analysis show that there are external factors that determine the effectiveness of project implementation which include the use of the internet to find information sources, the use of the e-mail as a means of correspondence communication and always resolving problems with the community if there is a dispute. Meanwhile, the internal factors that determine the effectiveness of project implementation are the commitments that have been made between the owner and the contractor on time, making the work results more qualified and productive and able to jointly solve conflicts in the project.
\end{abstract}

Keywords: Construction Projects, External Factors, Internal Factors, Effectiveness 


\section{PENDAHULUAN}

DKI Jakarta adalah ibu kota negara terbesar di Indonesia dan kota metropolitan yang padat penduduk karena memiliki tingkat pertumbuhan dan arus mobilitas manusia yang tinggi, baik dari masyarakat DKI Jakarta maupun dari masyarakat luar daerah di sekitarnya yang menggantungkan hidup di kota Jakarta. Kedudukan Jakarta menjadi pusat pemerintahan sekaligus juga pusat kegiatan perekonomian yang menyebabkan dampak pada perkembangan roda kehidupan ekonomi, sosial dan budaya secara umum.

Melihat pertumbuhan kota Jakarta yang begitu pesat disebabkan oleh beberapa faktor seperti perkantoran, perdagangan, pemerintahan, bisnis dan permukiman yang tinggi menyebabkan masyarakat cenderung untuk mencari penghasilan di kota Jakarta. Sektor perdagangan juga sangat berpengaruh terhadap tingkat perekonomian di Jakarta seperti kawasan Jalan Haji Agus Salim atau biasa yang dikenal oleh warga Jakarta dengan Jalan Sabang.

Kawasan Jalan Sabang yang berada di kelurahan Kebon Sirih terdapat beraneka ragam penginapan, mulai dari penginapan melati, hotel budget sampai hotel berbintang. Sebagian besar pengunjungnya adalah pebisnis, pengusaha dan wisatawan, baik dari warga luar Jakarta maupun wisatawan mancanegara, yang memiliki kepentingan dan memilih lokasi yang strategis untuk keperluan bisnis nya. Banyak pendatang yang menetap biasanya untuk tinggal dan tidak sedikit juga yang menetap hanya saat mereka bekerja. Hal ini menyebabkan kebutuhan dan permintaan akan tempat tinggal juga menjadi meningkat. Untuk mengatasi keterbatasan lahan untuk hunian di wilayah Jakarta, hunian vertikal menjadi pilihan sebagai jawaban untuk hal ini.

PT Prima Hotel Indonesia menyikapi hal tersebut menjadi sebuah peluang untuk bisa mendukung perekonomian yang terjadi pada kawasan tersebut. PT Prima Hotel Indonesia yang merupakan anak perusahaan dari PT Ramayana Lestari Sentosa didirikan pada tahun 2015 dengan visi membangun dan mengoperasikan hotel ramah wisatawan mulai dari hotel budget hingga hotel bintang 4 yang dapat mendukung perekonomian dan menambah fasilitas yang nyaman di suatu kawasan.

Pada setiap proyek pembangunan yang dilaksanakan oleh PT Prima Hotel Indonesia harus memperhatikan setiap faktor-faktor eksternal dan internal yang menjadi penentu proyek tersebut efektif atau tidak dalam pelaksanaannya. Efektivitas yang berjalan dengan baik, dan keberhasilan dari suatu proyek yang berjalan dengan tepat waktu merupakan hubungan antara output dengan tujuan. Semakin besar kontribusi output terhadap pencapaian tujuan, maka akan semakin efektif organisasi, program atau kegiatan proyek tersebut.

\section{TINJAUAN PUSTAKA}

Proyek konstruksi merupakan proyek yang berkaitan dengan pembangunan suatu bangunan dan infrastruktur yang umumnya mencakup pekerjaan pokok yang termasuk dalam bidang teknik sipil dan arsitektur (Widiasanti dan Lenggogeni, 2013). Selain itu, juga melibatkan bidang ilmu lainnya, seperti teknik industri, mesin, elektro, geoteknik dan landscape. Kegiatan proyek konstruksi adalah usaha untuk memenuhi kebutuhan manusia karena setiap kegiatan yang dilakukan berfungsi untuk kepentingan masyarakat umum. Oleh karena itu proyek konstruksi ini menjadi suatu kegiatan yang sangat penting dan memerlukan manajemen yang baik, karena banyak kegagalan konstruksi terjadi dikarenakan manajemen proyek yang tidak baik.

Efektivitas adalah suatu ukuran yang menyatakan apakah suatu manajemen yang dilakukan telah berhasil dicapai dengan ketetapan dan tujuan yang ditentukan. Efektivitas selalu berkaitan dengan hasil yang diharapkan dan tujuan yang telah dicapai, sehingga efektivitas memberikan kontribusi terhadap kegiatan yang dicapai. 
Menurut Toor dan Ongunlana dalam jurnal (Hwang dan Lim, 2013) menjelaskan bahwa tingkat keberhasilan suatu proyek ditunjukkan dengan elemen tertentu yang secara signifikan berkontribusi dan sangat penting untuk keberhasilan suatu proyek. Oleh karena itu, untuk mengetahui dan memastikan keberhasilan proyek, seseorang harus terlebih dahulu dan terutama dapat menentukan faktor-faktor yang mempengaruhi efektivitas keberhasilan suatu proyek dan kegagalan suatu proyek. Meskipun demikian, tidak ada definisi secara luas untuk mengetahui tingkat keberhasilan suatu proyek.

kemudahan jaminan Bank dan dukungan dalam permodalan dan sumber daya konstruksi.

Faktor eksternal dalam efektivitas pelaksanaan proyek pembangunan hotel antara lain yaitu: faktor lingkungan (alam. Cuaca), faktor sosial (adat, budaya serta kondisi masyarakat), faktor politik dan hukum (kebijakan pemerintah), faktor teknologi dan faktor ekonomi. Sedangkan faktor-faktor internal dalam efektivitas pelaksanaan proyek pembangunan hotel antara lain adalah: faktor manajemen risiko (K3), faktor sumber daya (tenaga kerja, material/bahan dan peralatan), faktor manajemen proyek, faktor organisasi dan faktor manajemen kualitas.

\section{METODE PENELITIAN}

Jenis penelitian yang digunakan adalah eksplanatori yaitu metode survei kuesioner yaitu sebuah penelitian atau survei yang metode dan alat pengumpulan data informasinya diperoleh melalui responden dengan mengisi kuesioner. Penelitian ini menggunakan analisis karakteristik responden yang berlatarbelakang responden terhadap sample penelitian yang sudah ditentukan.

Penentuan pakar dalam validitas isi dilakukan dengan cara survei kuesioner terhadap para pakar. Adapun para pakar diminta untuk mengamati secara cermat semua item dalam tes. Kemudian mereka
Pelaksanaan proyek konstruksi tidak lepas dari berbagai permasalahan baik internal dan eksternal yang mempengaruhi keberhasilan suatu proyek konstruksi. Faktor internal proyek merupakan faktor yang berasal dari dalam proyek baik dari pemilik, perencana, kontraktor atau konsultan. Sedangkan faktor eksternal merupakan faktor yang berasal dari luar proyek konstruksi. Kebijakan pemerintah terhadap pelaku usaha jasa konstruksi sangat berperan penting karena merupakan aturan mekanisme pemberlakuan subkontrak agar tidak terjadi monopoli, memfasilitasi

diminta untuk melakukan koreksi terhadap semua item yang telah dibuat. Pada akhir perbaikan, para pakar diminta untuk memberikan pertimbangan tentang bagaimana tes tersebut dapat menggambarkan si dari variabel yang akan diukur. Jumlah pakar dalam penelitian ditentukan sebanyak 2 pakar. Populasi penelitian ini meliputi kontraktor struktur dan arsitektur, kontraktor mekanikal, elektrikal dan plumbing, dan kontraktor interior. Jumlah sampel dalam penelitian ditentukan sebanyak 33 sampel.

Seluruh variabel dalam penelitian ini diukur dengan menggunakan skala Likert. Menurut Sugiyono (2012), skala Likert ini digunakan untuk mengukur sikap, pendapat, pengaruh dan persepsi seseorang atau sekelompok orang tentang fenomena sosial.

Dalam penelitian ini skala Likert yang digunakan adalah skala dengan lima tingkatan. Adapun pemberian skor pada setiap jawaban tersebut diatur sebagai berikut; sangat setuju (5), setuju (4), raguragu (3), tidak setuju (2) dan sangat tidak setuju (1).

Uji validitas merupakan suatu alat ukur untuk mengetahui seberapa tepat suatu alat ukur mampu melakukan fungsi. Uji reliabilitas dilakukan untuk mengetahui keteraturan hasil pengukuran apabila instrumen tersebut digunakan sebagai alat ukur suatu responden. Semakin tinggi 
nilainya, berarti tinggi pula tingkat keandalannya.

Data dalam penelitian tidak berguna bila alat pengukuran yang digunakan memiliki reliabilitas dan validitas yang tinggi. Uji reliabilitas dan validitas memberikan informasi tentang data yang dikumpulkan betul-betul menggambarkan fenomena yang ingin diukur.

Teknik analisis data yang digunakan untuk membahas permasalahan dalam penelitian ini adalah analisis Relative Importance Index (RII) yaitu analisis yang memungkinkan suatu kuantitatif relative, di mana semakin tinggi peringkat semakin tinggi pula pengaruh yang diberikan oleh variabel yang dimiliki. Dalam penelitian ini, faktor eksternal dan internal dalam efektivitas proyek pembangunan Hotel Ashley Sabang ditentukan dari 10 nilai variabel teratas berdasarkan peringkat relative importance index (RII).

\section{Analisis Dan Pembahasan}

Responden yang digunakan sebanyak 33 staf yang bekerja pada masing-masing kontraktor di proyek Pembangunan Hotel Ashley Sabang. Data responden tersebut akan dilakukan analisis statistik deskriptif untuk lebih dapat diketahui secara jelas mengenai frekuensi data responden, analisis dilakukan dengan menggunakan program statistik.

\section{Rancangan kuesioner}

Pada tahap pertama ini semua indikator di susun dari kajian yang telah peneliti kumpulkan dengan pengumpulan data melalui penyebaran data kuesioner, pentabulasian data lalu pengolahan data.

Tabel 1. Reduksi Variabel Validasi Responden

\begin{tabular}{lcll}
\hline \multicolumn{1}{c}{ Variabel } & Indikator & \multicolumn{1}{c}{ Faktor } \\
\hline Faktor & $\mathrm{X}_{1.1}$ & $\begin{array}{l}\text { Intensitas } \\
\text { hujan tinggi }\end{array}$ & curah \\
Lingkungan & & hjen \\
\hline
\end{tabular}

\begin{tabular}{|c|c|c|}
\hline Variabel & Indikator & Faktor \\
\hline \multirow[t]{7}{*}{$\begin{array}{l}\text { (alam, } \\
\text { cuaca) }\end{array}$} & $\mathrm{X}_{1.2}$ & $\begin{array}{l}\text { Kondisi lahan tanah } \\
\text { yang tidak terduga }\end{array}$ \\
\hline & $\mathrm{X}_{1.3}$ & $\begin{array}{l}\text { Kondisi lingkungan } \\
\text { kerja yang buruk }\end{array}$ \\
\hline & $\mathrm{X}_{1.4}$ & $\begin{array}{l}\text { Akses ke lokasi } \\
\text { proyek sangat sulit }\end{array}$ \\
\hline & $\mathrm{X}_{1.5}$ & $\begin{array}{l}\text { Kondisi force } \\
\text { majeure yang tidak } \\
\text { bisa dikendalikan }\end{array}$ \\
\hline & $\mathrm{X}_{1.6}$ & $\begin{array}{l}\text { Tingkat kebisingan } \\
\text { berlebihan }\end{array}$ \\
\hline & $\mathrm{X}_{1.7}$ & $\begin{array}{l}\text { Kerusakan sumber } \\
\text { daya alam sekitar } \\
\text { seperti tumbuhan } \\
\text { atau hewan }\end{array}$ \\
\hline & $\mathrm{X}_{1.8}$ & $\begin{array}{l}\text { Kegagalan dalam } \\
\text { penempatan tata } \\
\text { letak peralatan } \\
\text { proyek }\end{array}$ \\
\hline \multirow{7}{*}{$\begin{array}{l}\text { Faktor } \\
\text { Sosial (adat, } \\
\text { budaya } \\
\text { serta } \\
\text { kondisi } \\
\text { masyarakat) }\end{array}$} & $\mathrm{X}_{2.1}$ & $\begin{array}{l}\text { Kesulitan dalam } \\
\text { pembebasan lahan } \\
\text { di sekitar proyek }\end{array}$ \\
\hline & $\mathrm{X}_{2.2}$ & $\begin{array}{l}\text { Padatnya penduduk } \\
\text { yang bermukim di } \\
\text { area proyek }\end{array}$ \\
\hline & $\mathrm{X}_{2.3}$ & $\begin{array}{l}\text { Pencahayaan yang } \\
\text { kurang baik }\end{array}$ \\
\hline & $\mathrm{X}_{2.4}$ & $\begin{array}{l}\text { Tingkat lalu lintas } \\
\text { yang kurang } \\
\text { memadai }\end{array}$ \\
\hline & $\mathrm{X}_{2.5}$ & $\begin{array}{lr}\text { Kerusakan } & \text { lahan } \\
\text { masyarakat } & \text { yang } \\
\text { berdekatan } & \end{array}$ \\
\hline & $\mathrm{X}_{2.6}$ & $\begin{array}{l}\text { Situasi dan kondisi } \\
\text { di sekitar proyek } \\
\text { yang mengganggu } \\
\text { aktifitas } \\
\text { perkantoran }\end{array}$ \\
\hline & $\mathrm{X}_{2.7}$ & $\begin{array}{l}\text { Selalu } \\
\text { menyelesaikan } \\
\text { masalah dengan } \\
\text { masyarakat jika ada } \\
\text { perselisihan }\end{array}$ \\
\hline \multirow{2}{*}{$\begin{array}{l}\text { Faktor } \\
\text { Politik dan } \\
\text { Hukum } \\
\text { (Kebijakan } \\
\text { Pemerintah) }\end{array}$} & $\mathrm{X}_{3.1}$ & $\begin{array}{lr}\text { Adanya kebijakan } \\
\text { moneter } \\
\text { diperbaharui }\end{array}$ \\
\hline & $\mathrm{X}_{3.2}$ & $\begin{array}{l}\text { Situasi sosial politik } \\
\text { yang kurang stabil }\end{array}$ \\
\hline
\end{tabular}




\begin{tabular}{|c|c|c|}
\hline Variabel & Indikator & Faktor \\
\hline & $\mathrm{X}_{3.3}$ & $\begin{array}{l}\text { Nilai tukar mata } \\
\text { uang yang semakin } \\
\text { tinggi }\end{array}$ \\
\hline & $\mathrm{X}_{3.4}$ & $\begin{array}{l}\text { Kenaikan harga } \\
\text { BBM }\end{array}$ \\
\hline & $\mathrm{X}_{3.5}$ & $\begin{array}{l}\text { Sistem regulasi } \\
\text { perpajakan yang } \\
\text { kurang efisien }\end{array}$ \\
\hline & $\mathrm{X}_{3.6}$ & $\begin{array}{l}\text { Adanyaketerlibatan } \\
\text { demonstrasi akibat } \\
\text { sistem politik di } \\
\text { negara yang tidak } \\
\text { bagus }\end{array}$ \\
\hline \multirow[t]{6}{*}{$\begin{array}{l}\text { Faktor } \\
\text { Teknologi }\end{array}$} & $\mathrm{X}_{4.1}$ & $\begin{array}{lr}\text { Penggunaan } & \\
\text { internet } & \text { untuk } \\
\text { mencari } & \text { sumber } \\
\text { informasi } & \end{array}$ \\
\hline & $\mathrm{X}_{4.2}$ & $\begin{array}{l}\text { Tingkat penggunaan } \\
\text { teknologi relatif } \\
\text { tinggi }\end{array}$ \\
\hline & $\mathrm{X}_{4.3}$ & $\begin{array}{l}\text { Teknologi dijadikan } \\
\text { alat ukur } \\
\text { keberhasilan } \\
\text { proyek }\end{array}$ \\
\hline & $\mathrm{X}_{4.4}$ & $\begin{array}{l}\text { Kepuasan pengguna } \\
\text { terhadap sistem } \\
\text { teknologi yang telah } \\
\text { digunakan }\end{array}$ \\
\hline & $\mathrm{X}_{4.5}$ & $\begin{array}{l}\text { Pemakaian media e- } \\
\text { mail sebagai alat } \\
\text { komunikasi surat } \\
\text { menyurat }\end{array}$ \\
\hline & $\mathrm{X}_{4.6}$ & $\begin{array}{l}\text { Kurangnya } \\
\text { pemahaman secara } \\
\text { luas mengenai ilmu } \\
\text { teknologi yang } \\
\text { sudah berkembang }\end{array}$ \\
\hline \multirow[t]{4}{*}{$\begin{array}{l}\text { Faktor } \\
\text { Teknologi }\end{array}$} & $\mathrm{X}_{5.1}$ & $\begin{array}{l}\text { Inflasi dan suku } \\
\text { bunga tinggi }\end{array}$ \\
\hline & $\mathrm{X}_{5.2}$ & $\begin{array}{l}\text { Estimasi biaya } \\
\text { proyek sudah tepat }\end{array}$ \\
\hline & $\mathrm{X}_{5.3}$ & $\begin{array}{l}\text { Kondisi modal kerja } \\
\text { penyedia jasa } \\
\text { kurang baik }\end{array}$ \\
\hline & $\mathrm{X}_{5.4}$ & $\begin{array}{l}\text { Manajemen } \\
\text { perencanaan } \\
\text { keuangan yang } \\
\text { tidak baik }\end{array}$ \\
\hline
\end{tabular}

\begin{tabular}{|c|c|c|}
\hline Variabel & Indikator & Faktor \\
\hline & $\mathrm{X}_{5.5}$ & $\begin{array}{l}\text { Keterlambatan } \\
\text { pembayaran termin } \\
\text { dari owner }\end{array}$ \\
\hline & $\mathrm{X}_{5.6}$ & $\begin{array}{lr}\text { Perhitungan } & \text { yang } \\
\text { kurang baik } & \text { dalam } \\
\text { rencana } & \text { biaya } \\
\text { material } & \text { dan } \\
\text { peralatan } & \end{array}$ \\
\hline & $\mathrm{X}_{5.7}$ & $\begin{array}{l}\text { Dapat dengan tepat } \\
\text { mengelola anggaran } \\
\text { biaya proyek yang } \\
\text { telah direncanakan }\end{array}$ \\
\hline & $\mathrm{X}_{5.8}$ & $\begin{array}{l}\text { Pengajuan progres } \\
\text { kontraktor ke } \\
\text { owner yang kurang } \\
\text { efisien dan efektif }\end{array}$ \\
\hline & $\mathrm{X}_{5.9}$ & $\begin{array}{l}\text { Ketersediaan dan } \\
\text { ketepatan alokasi } \\
\text { dana }\end{array}$ \\
\hline \multirow[t]{8}{*}{$\begin{array}{l}\text { Faktor } \\
\text { Manajemen } \\
\text { Risiko (K3) }\end{array}$} & $\mathrm{X}_{6.1}$ & $\begin{array}{l}\text { Menekan risiko } \\
\text { yang timbul sekecil } \\
\text { mungkin }\end{array}$ \\
\hline & $\mathrm{X}_{6.2}$ & $\begin{array}{l}\text { Lemahnya respon } \\
\text { jika terjadi } \\
\text { kecelakaan kerja }\end{array}$ \\
\hline & $\mathrm{X}_{6.3}$ & $\begin{array}{l}\text { Pemilihan metode } \\
\text { pelaksanaan } \\
\text { konstruksi tidak } \\
\text { diperhitungkan oleh } \\
\text { aspek risiko }\end{array}$ \\
\hline & $\mathrm{X}_{6.4}$ & $\begin{array}{l}\text { Safety factor pada } \\
\text { pelaksanaan masih } \\
\text { sangat kurang }\end{array}$ \\
\hline & $\mathrm{X}_{6.5}$ & $\begin{array}{l}\text { Kegagalan } \\
\text { menggunakan Alat } \\
\text { Pelindung Diri } \\
\text { (APD) dengan benar }\end{array}$ \\
\hline & $\mathrm{X}_{6.6}$ & $\begin{array}{lr}\text { Sering } & \text { tidak } \\
\text { mengikuti } & \text { Safety } \\
\text { Talk harian } & \end{array}$ \\
\hline & $\mathrm{X}_{6.7}$ & $\begin{array}{l}\text { Kesadaran } \\
\text { pemahaman akan } \\
\text { arti kesehatan dan } \\
\text { keselamatan kerja }\end{array}$ \\
\hline & $\mathrm{X}_{6.8}$ & $\begin{array}{l}\text { Kurangnya } \\
\text { penyediaan APD di } \\
\text { proyek }\end{array}$ \\
\hline
\end{tabular}




\begin{tabular}{|c|c|c|}
\hline Variabel & Indikator & Faktor \\
\hline \multirow[t]{13}{*}{$\begin{array}{l}\text { Faktor } \\
\text { Sumber } \\
\text { Daya }\end{array}$} & $X_{7.1}$ & $\begin{array}{lr}\text { Tenaga kerja tidak } \\
\text { memiliki } & \\
\text { keterampilan } & \text { dan } \\
\text { keahlian } & \text { di } \\
\text { bidangnya } & \end{array}$ \\
\hline & $\mathrm{X}_{7.2}$ & $\begin{array}{l}\text { Kenaikan harga } \\
\text { material }\end{array}$ \\
\hline & $\mathrm{X}_{7.3}$ & $\begin{array}{l}\text { Keterlambatan } \\
\text { material atau bahan } \\
\text { pada saat } \\
\text { pelaksanaan }\end{array}$ \\
\hline & $\mathrm{X}_{7.4}$ & $\begin{array}{lr}\text { Tenaga kerja } & \text { yang } \\
\text { lembur } & \text { akan } \\
\text { menyebabkan } & \\
\text { efisiensi } & \text { dan } \\
\text { efektivitas } & \text { dalam } \\
\text { bekerja } & \\
\end{array}$ \\
\hline & $X_{7.5}$ & $\begin{array}{l}\text { Upah tenaga kerja } \\
\text { yang tinggi }\end{array}$ \\
\hline & $\mathrm{X}_{7.6}$ & $\begin{array}{l}\text { Kontrol kualitas } \\
\text { material yang buruk }\end{array}$ \\
\hline & $\mathrm{X}_{7.7}$ & $\begin{array}{ll}\text { Harga } & \text { sewa } \\
\text { peralatan } & \text { yang } \\
\text { sangat mahal } & \end{array}$ \\
\hline & $\mathrm{X}_{7.8}$ & $\begin{array}{lr}\text { Kekurangan } & \text { tenaga } \\
\text { kerja } & \text { saat } \\
\text { pelaksanaan } & \text { di } \\
\text { proyek } & \\
\end{array}$ \\
\hline & $X_{7.9}$ & $\begin{array}{l}\text { Komposisi yang } \\
\text { baik dalam } \\
\text { menempatkan } \\
\text { kelompok kerja } \\
\text { seperti tukang besi, } \\
\text { tukang batu dan } \\
\text { lain-lain }\end{array}$ \\
\hline & $X_{7.10}$ & $\begin{array}{l}\text { Keterbatasan waktu } \\
\text { pelaksanaan dari } \\
\text { awal sampai } \\
\text { berakhir nya proyek }\end{array}$ \\
\hline & $\mathrm{X}_{7.111}$ & $\begin{array}{l}\text { Tidak adanya } \\
\text { ketersediaan bahan } \\
\text { material yang akan } \\
\text { digunakan pada saat } \\
\text { pelaksanaan proyek }\end{array}$ \\
\hline & $X_{7.12}$ & $\begin{array}{l}\text { Pelatihan dan } \\
\text { pengawasan yang } \\
\text { kurang memadai }\end{array}$ \\
\hline & $\mathrm{X}_{7.13}$ & $\begin{array}{l}\text { Tempat } \\
\text { penyimpanan }\end{array}$ \\
\hline
\end{tabular}

\begin{tabular}{|c|c|c|}
\hline Variabel & Indikator & Faktor \\
\hline & & $\begin{array}{l}\text { material bahan yang } \\
\text { kurang memadai }\end{array}$ \\
\hline \multirow[t]{10}{*}{$\begin{array}{l}\text { Faktor } \\
\text { Manajemen } \\
\text { Proyek }\end{array}$} & $\mathrm{X}_{8.1}$ & $\begin{array}{l}\text { Susunan organisasi } \\
\text { yang tepat dalam } \\
\text { menangani proyek }\end{array}$ \\
\hline & $\mathrm{X}_{8.2}$ & $\begin{array}{l}\text { Sering terjadi } \\
\text { kesalahan dan } \\
\text { perubahan desain }\end{array}$ \\
\hline & $\mathrm{X}_{8.3}$ & $\begin{array}{l}\text { Kurangnya disiplin } \\
\text { dalam menjalankan } \\
\text { standar SOP }\end{array}$ \\
\hline & $\mathrm{X}_{8.4}$ & $\begin{array}{l}\text { Efisiensi biaya, } \\
\text { sumber daya dan } \\
\text { waktu dengan baik }\end{array}$ \\
\hline & $\mathrm{X}_{8.5}$ & $\begin{array}{l}\text { Mengontrol } \\
\text { pekerjaan, biaya, } \\
\text { sumber daya dan } \\
\text { waktu dengan baik }\end{array}$ \\
\hline & $\mathrm{X}_{8.6}$ & $\begin{array}{l}\text { Menetapkan } \\
\text { anggota tim proyek } \\
\text { sesuai dengan } \\
\text { keahliannya }\end{array}$ \\
\hline & $\mathrm{X}_{8.7}$ & $\begin{array}{l}\text { Adanya perubahan } \\
\text { ruang lingkup yang } \\
\text { kurang baik }\end{array}$ \\
\hline & $\mathrm{X}_{8.8}$ & $\begin{array}{l}\text { Tujuan teknis dari } \\
\text { proyek konstruksi } \\
\text { tercapai }\end{array}$ \\
\hline & $\mathrm{X}_{8.9}$ & \begin{tabular}{l}
\multicolumn{2}{l}{ Mengkondisikan } \\
dan mengontrol \\
pelaksaan proyek \\
sehingga dapat \\
berjalan dengan \\
baik
\end{tabular} \\
\hline & $\mathrm{X}_{8.10}$ & \begin{tabular}{lr}
\multicolumn{2}{l}{ Metode } \\
pelaksanaan & dari \\
setiap & kegiatan \\
proyek & dapat \\
dijalankan & dengan \\
efektif &
\end{tabular} \\
\hline \multirow[t]{3}{*}{$\begin{array}{l}\text { Faktor } \\
\text { Organisasi }\end{array}$} & $\mathrm{X}_{9.1}$ & $\begin{array}{l}\text { Komunikasi dan } \\
\text { koordinasi proyek } \\
\text { tidak berjalan } \\
\text { dengan baik }\end{array}$ \\
\hline & $\mathrm{X}_{9.2}$ & $\begin{array}{l}\text { Membuat tim } \\
\text { proyek menjadi } \\
\text { kreatif dan inovatif }\end{array}$ \\
\hline & $\mathrm{X}_{9.3}$ & $\begin{array}{l}\text { Perencanaan dan } \\
\text { pelaksanaan }\end{array}$ \\
\hline
\end{tabular}




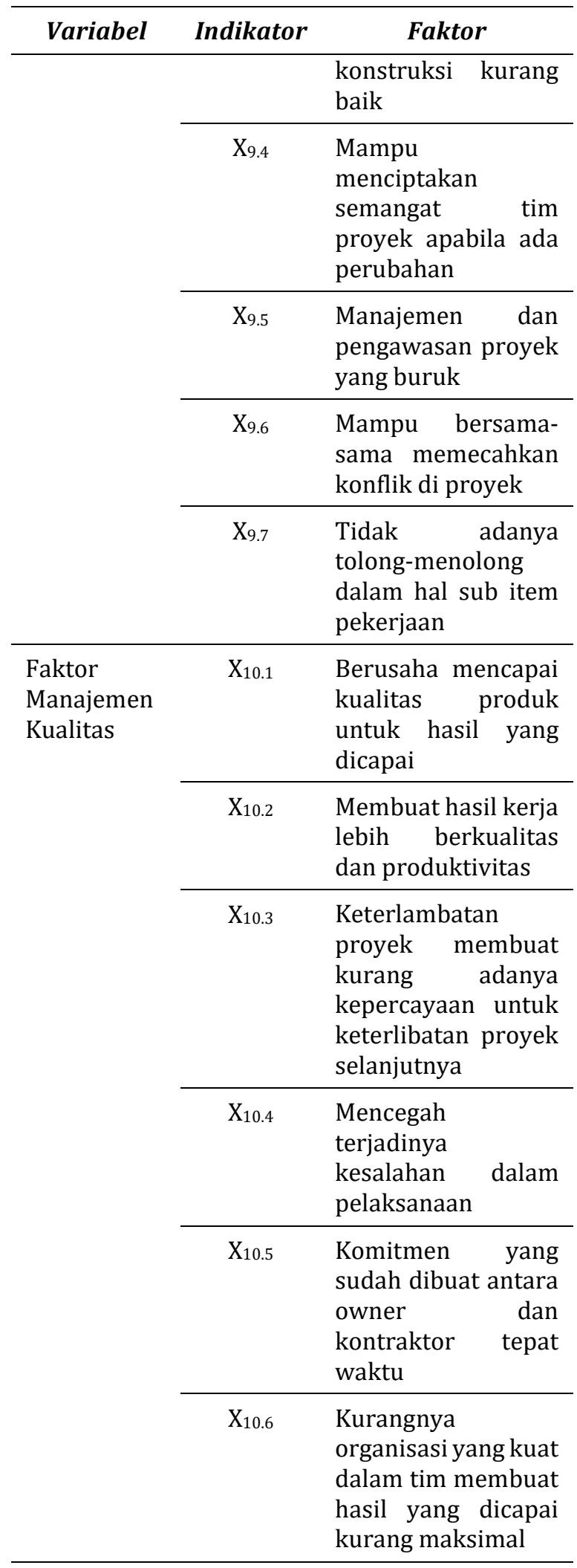

Setelah tahap pertama dilanjutkan melakukan validasi kepada 2 orang pakar. Validitas isi umumnya ditentukan melalui pertimbangan para pakar (expert), karena belum ada formula matematis untuk menghitung dan tidak ada cara untuk menunjukkan hasil secara pasti. Fungsi dari validitas isi yaitu untuk menggambarkan bagaimana suatu tes divalidasi dengan menggunakan validitas isi. Dalam penelitian ini, validitas isi dilakukan dengan cara survei kuesioner terhadap para pakar.

\section{Karakteristik responden}

Tabel 2. Frekuensi Responden Berdasarkan Jenis Kelamin

\begin{tabular}{ccc}
\hline $\begin{array}{c}\text { Jenis } \\
\text { Kelamin }\end{array}$ & $\begin{array}{c}\text { Frekuensi } \\
\text { (orang) }\end{array}$ & $\begin{array}{c}\text { Persentase } \\
\text { (\%) }\end{array}$ \\
\hline Laki-laki & 31 & 93.94 \\
\hline Perempuan & 2 & 6.06 \\
\hline Jumlah & 33 & 100 \\
\hline
\end{tabular}

Dari Tabel 2 dapat disimpulkan bahwa jumlah responden laki-laki sebanyak 33 orang responden (9394/5) dan 6.06\% wanita dengan jumlah 2 responden (6.06\%), sehingga dapat disimpulkan bahwa responden pada penelitian ini sebagian besar adalah pria.

Tabel 3. Frekuensi Responden Berdasarkan Tingkat Pendidikan

\begin{tabular}{ccc}
\hline Pendidikan & $\begin{array}{c}\text { Frekuensi } \\
\text { (orang) }\end{array}$ & $\begin{array}{c}\text { Persentase } \\
\text { (\%) }\end{array}$ \\
\hline $\begin{array}{c}\text { SMA } \\
\text { Sederajat }\end{array}$ & 12 & 36.40 \\
\hline Diploma & 7 & 21.20 \\
\hline $\begin{array}{c}\text { Sarjana } \\
\text { Strata 1 }\end{array}$ & 13 & 39.40 \\
\hline $\begin{array}{c}\text { Sarjana } \\
\text { Strata 2 }\end{array}$ & 1 & 3.00 \\
\hline Jumlah & 33 & 100 \\
\hline
\end{tabular}

Dari Tabel 3 dapat disimpulkan bahwa tingkat pendidikan responden dalam penelitian ini dengan pendidikan terakhir SMA Sederajat dengan dengan jumlah 12 
orang (36.40\%), Diploma dengan jumlah 7 orang (21.20\%), Sarjana strata 1 dengan 13 orang (39.40\%) dan Sarjana strata 2 dengan 1 responden (3\%), sehingga dapat disimpulkan jumlah responden terbesar rata-rata memiliki tingkat pendidikan Sarjana strata 1 dan SMA Sederajat.

Tabel 4. Frekuensi Responden Berdasarkan Lama Bekerja

\begin{tabular}{ccc}
\hline $\begin{array}{c}\text { Lama } \\
\text { Bekerja } \\
\text { (Tahun) }\end{array}$ & $\begin{array}{c}\text { Frekuensi } \\
\text { (orang) }\end{array}$ & $\begin{array}{c}\text { Persentase } \\
\text { (\%) }\end{array}$ \\
\hline < 5Tahun & 7 & 21.20 \\
\hline 6 - 10 Tahun & 5 & 18.20 \\
\hline > 10 Tahun & 20 & 60.60 \\
\hline Jumlah & 33 & 100 \\
\hline
\end{tabular}

Dari Tabel 4 dapat disimpulkan bahwa karakteristik responden dalam penelitian ini jika dilihat dari lamanya bekerja menjadi pelaku konstruksi, paling besar adalah para pelaku konstruksi yang sudah bekerja selama lebih dari 10 tahun dengan persentase $60,60 \%$. Pelaku konstruksi yang bekerja dalam kurun waktu 6 sampai dengan 10 tahun berjumlah 6 responden dengan persentase 18,20\%. Sedangkan sisanya adalah responden yang baru bekerja selama kurang dari sama dengan 5 tahun berjumlah 7 orang dengan persentase $21,20 \%$.

Tabel 5. Frekuensi Responden Berdasarkan Pelaku Konstruksi

\begin{tabular}{ccc}
\hline $\begin{array}{c}\text { Pelaku } \\
\text { Konstruksi }\end{array}$ & $\begin{array}{c}\text { Frekuensi } \\
\text { (orang) }\end{array}$ & $\begin{array}{c}\text { Persentase } \\
\text { (\%) }\end{array}$ \\
\hline $\begin{array}{c}\text { Struktur \& } \\
\text { Arsitektur }\end{array}$ & 17 & 51.50 \\
\hline MEP & 9 & 27.30 \\
\hline Interior & 7 & 21.20 \\
\hline Jumlah & 33 & 100 \\
\hline
\end{tabular}

Dari Tabel 5 dapat disimpulkan bahwa responden dalam penelitian ini dibagi menjadi 3 kelompok kontraktor, yaitu Kontraktor Struktur dan Arsitektur dengan jumlah 17 orang (51.50\%), Kontraktor Mekanikal Elektrikal dan Plumbing dengan jumlah 9 orang $(27.30 \%)$ dan Kontraktor Interior dengan jumlah 7 orang (21.20\%).

\section{Uji validitas dan reabilitas}

Tabel 6. Hasil Uji Validitas Variabel Faktor Eksternal

\begin{tabular}{|c|c|c|c|}
\hline Variabel & Indikator & $\begin{array}{c}r \\
\text { hitung }\end{array}$ & r tabel \\
\hline \multirow{8}{*}{$\begin{array}{l}\text { Faktor } \\
\text { Lingkungan } \\
\text { (alam, } \\
\text { cuaca) }\end{array}$} & $\mathrm{X}_{1.1}$ & 0.484 & 0.344 \\
\hline & $\mathrm{X}_{1.2}$ & 0.510 & 0.344 \\
\hline & $\mathrm{X}_{1.3}$ & 0.729 & 0.344 \\
\hline & $\mathrm{X}_{1.4}$ & 0.582 & 0.344 \\
\hline & $\mathrm{X}_{1.5}$ & 0.597 & 0.344 \\
\hline & $\mathrm{X}_{1.6}$ & 0.591 & 0.344 \\
\hline & $\mathrm{X}_{1.7}$ & 0.638 & 0.344 \\
\hline & $\mathrm{X}_{1.8}$ & 0.612 & 0.344 \\
\hline \multirow{7}{*}{$\begin{array}{l}\text { Faktor } \\
\text { Sosial (adat, } \\
\text { budaya serta } \\
\text { kondisi } \\
\text { masyarakat) }\end{array}$} & $\mathrm{X}_{2.1}$ & 0.772 & 0.344 \\
\hline & $\mathrm{X}_{2.2}$ & 0.758 & 0.344 \\
\hline & $\mathrm{X}_{2.3}$ & 0.721 & 0.344 \\
\hline & $\mathrm{X}_{2.4}$ & 0.751 & 0.344 \\
\hline & $\mathrm{X}_{2.5}$ & 0.759 & 0.344 \\
\hline & $\mathrm{X}_{2.6}$ & 0.628 & 0.344 \\
\hline & $\mathrm{X}_{2.7}$ & 0.657 & 0.344 \\
\hline \multirow{6}{*}{$\begin{array}{l}\text { Faktor } \\
\text { Politik dan } \\
\text { Hukum } \\
\text { (Kebijakan } \\
\text { Pemerintah) }\end{array}$} & $\mathrm{X}_{3.1}$ & 0.434 & 0.344 \\
\hline & $\mathrm{X}_{3.2}$ & 0.556 & 0.344 \\
\hline & $\mathrm{X}_{3.3}$ & 0.512 & 0.344 \\
\hline & $\mathrm{X}_{3.4}$ & 0.656 & 0.344 \\
\hline & $\mathrm{X}_{3.5}$ & 0.639 & 0.344 \\
\hline & $\mathrm{X}_{3.6}$ & 0.644 & 0.344 \\
\hline \multirow{5}{*}{$\begin{array}{l}\text { Faktor } \\
\text { Teknologi }\end{array}$} & $\mathrm{X}_{4.1}$ & 0.507 & 0.344 \\
\hline & $\mathrm{X}_{4.2}$ & 0.636 & 0.344 \\
\hline & $\mathrm{X}_{4.3}$ & 0.580 & 0.344 \\
\hline & $\mathrm{X}_{4.4}$ & 0.567 & 0.344 \\
\hline & $\mathrm{X}_{4.5}$ & 0.476 & 0.344 \\
\hline
\end{tabular}




\begin{tabular}{lccc}
\hline \multirow{2}{*}{ Variabel } & Indikator & $\begin{array}{c}\boldsymbol{r} \\
\text { hitung }\end{array}$ & r tabel \\
\hline \multirow{2}{*}{$\begin{array}{l}\text { Faktor } \\
\text { Ekonomi }\end{array}$} & $\mathrm{X}_{4.6}$ & 0.627 & 0.344 \\
\cline { 2 - 4 } & $\mathrm{X}_{5.1}$ & 0.655 & 0.344 \\
\cline { 2 - 4 } & $\mathrm{X}_{5.2}$ & 0.654 & 0.344 \\
\cline { 2 - 4 } & $\mathrm{X}_{5.3}$ & 0.611 & 0.344 \\
\cline { 2 - 4 } & $\mathrm{X}_{5.4}$ & 0.720 & 0.344 \\
\cline { 2 - 4 } & $\mathrm{X}_{5.5}$ & 0.680 & 0.344 \\
\cline { 2 - 4 } & $\mathrm{X}_{5.6}$ & 0.755 & 0.344 \\
\hline $\mathrm{X}_{5.7}$ & 0.599 & 0.344 \\
\hline & $\mathrm{X}_{5.8}$ & 0.803 & 0.344 \\
\hline & $\mathrm{X}_{5.9}$ & 0.678 & 0.344 \\
\hline
\end{tabular}

\begin{tabular}{|c|c|c|c|}
\hline Variabel & Indikator & $\begin{array}{c}r \\
\text { hitung }\end{array}$ & rtabel \\
\hline & $\mathrm{X}_{7.9}$ & 0.538 & 0.344 \\
\hline & $X_{7.10}$ & 0.657 & 0.344 \\
\hline & $X_{7.11}$ & 0.780 & 0.344 \\
\hline & $\mathrm{X}_{7.12}$ & 0.685 & 0.344 \\
\hline & $X_{7.13}$ & 0.603 & 0.344 \\
\hline \multirow{10}{*}{$\begin{array}{l}\text { Faktor } \\
\text { Manejemen } \\
\text { Proyek }\end{array}$} & $\mathrm{X}_{8.1}$ & 0.703 & 0.344 \\
\hline & $\mathrm{X}_{8.2}$ & 0.676 & 0.344 \\
\hline & $\mathrm{X}_{8.3}$ & 0.581 & 0.344 \\
\hline & $\mathrm{X}_{8.4}$ & 0.466 & 0.344 \\
\hline & $\mathrm{X}_{8.5}$ & 0.530 & 0.344 \\
\hline & $\mathrm{X}_{8.6}$ & 0.669 & 0.344 \\
\hline & $\mathrm{X}_{8.7}$ & 0.620 & 0.344 \\
\hline & $\mathrm{X}_{8.8}$ & 0.385 & 0.344 \\
\hline & $\mathrm{X}_{8.9}$ & 0.607 & 0.344 \\
\hline & $\mathrm{X}_{8.10}$ & 0.392 & 0.344 \\
\hline \multirow{7}{*}{$\begin{array}{l}\text { Faktor } \\
\text { Organisasi }\end{array}$} & $\mathrm{X}_{9.1}$ & 0.537 & 0.344 \\
\hline & $\mathrm{X}_{9.2}$ & 0.445 & 0.344 \\
\hline & $\mathrm{X}_{9.3}$ & 0.489 & 0.344 \\
\hline & $\mathrm{X}_{9.4}$ & 0.571 & 0.344 \\
\hline & $\mathrm{X}_{9.5}$ & 0.443 & 0.344 \\
\hline & $\mathrm{X}_{9.6}$ & 0.479 & 0.344 \\
\hline & $\mathrm{X}_{9.7}$ & 0.479 & 0.344 \\
\hline \multirow{6}{*}{$\begin{array}{l}\text { Faktor } \\
\text { Manajemen } \\
\text { Kualitas }\end{array}$} & $\mathrm{X}_{10.1}$ & 0.439 & 0.344 \\
\hline & $\mathrm{X}_{10.2}$ & 0.516 & 0.344 \\
\hline & $\mathrm{X}_{10.3}$ & 0.581 & 0.344 \\
\hline & $\mathrm{X}_{10.4}$ & 0.597 & 0.344 \\
\hline & $\mathrm{X}_{10.5}$ & 0.611 & 0.344 \\
\hline & $\mathrm{X}_{10.6}$ & 0.611 & 0.344 \\
\hline
\end{tabular}

Berdasarkan uji validitas menggunakan program statistik diketahui bahwa dari 36 indikator pernyataan mengenai faktor eksternal, semua pernyataan adalah valid sehingga semua akan dipakai untuk analisis selanjutnya.

Tabel 7. Hasil Uji Validitas Variabel Faktor Internal

\begin{tabular}{|c|c|c|c|}
\hline Variabel & Indikator & $\begin{array}{c}r \\
\text { hitung }\end{array}$ & r tabel \\
\hline \multirow{8}{*}{$\begin{array}{l}\text { Faktor } \\
\text { Manajemen } \\
\text { Risiko (K3) }\end{array}$} & $X_{6.1}$ & 0.474 & 0.344 \\
\hline & $\mathrm{X}_{6.2}$ & 0.730 & 0.344 \\
\hline & $\mathrm{X}_{6.3}$ & 0.649 & 0.344 \\
\hline & $\mathrm{X}_{6.4}$ & 0.702 & 0.344 \\
\hline & $\mathrm{X}_{6.5}$ & 0.691 & 0.344 \\
\hline & $\mathrm{X}_{6.6}$ & 0.610 & 0.344 \\
\hline & $X_{6.7}$ & 0.420 & 0.344 \\
\hline & $\mathrm{X}_{6.8}$ & 0.716 & 0.344 \\
\hline \multirow{8}{*}{$\begin{array}{l}\text { Faktor } \\
\text { Sumber } \\
\text { Daya }\end{array}$} & $\mathrm{X}_{7.1}$ & 0.556 & 0.344 \\
\hline & $\mathrm{X}_{7.2}$ & 0.700 & 0.344 \\
\hline & $\mathrm{X}_{7.3}$ & 0.632 & 0.344 \\
\hline & $\mathrm{X}_{7.4}$ & 0.451 & 0.344 \\
\hline & $\mathrm{X}_{7.5}$ & 0.427 & 0.344 \\
\hline & $\mathrm{X}_{7.6}$ & 0.591 & 0.344 \\
\hline & $X_{7.7}$ & 0.817 & 0.344 \\
\hline & $\mathrm{X}_{7.8}$ & 0.762 & 0.344 \\
\hline
\end{tabular}

Berdasarkan uji validitas menggunakan program statistik diketahui bahwa dari 36 indikator pernyataan mengenai faktor internal, semua pernyataan adalah valid sehingga semua akan dipakai untuk analisis selanjutnya. 
Tabel 8. Hasil Uji Reliabilitas Variabel

\begin{tabular}{cc}
\hline Cronbach's Alpha & N of items \\
\hline .978 & 80 \\
\hline
\end{tabular}

Dari tabel di atas didapat hasil bahwa nilai $\mathrm{r}$ alpha adalah 0,978>0,60 maka dapat diambil kesimpulan bahwa variabel penelitian ini reliabel jadi semua variabel dinyatakan konsisten dan dapat dipercaya sebagai alat ukur.

\section{Analisis relative importance index (RII) berdasarkan faktor eksternal}

Tabel 9. Perhitungan Pemeringkatan Relative Importance Index (RII) Faktor Eksternal

\begin{tabular}{|c|c|c|}
\hline Faktor & Indikator & $\begin{array}{c}\text { Nilai } \\
\text { RII }\end{array}$ \\
\hline $\begin{array}{l}\text { Penggunaan internet } \\
\text { untuk mencari sumber } \\
\text { informasi }\end{array}$ & $\mathrm{X}_{4.1}$ & 77.576 \\
\hline $\begin{array}{l}\text { Pemakaian media e-mail } \\
\text { sebagai alat komunikasi } \\
\text { surat menyurat }\end{array}$ & $\mathrm{X}_{4.5}$ & 75.152 \\
\hline $\begin{array}{lr}\text { Selalu menyelesaikan } \\
\text { masalah } & \text { dengan } \\
\text { masyarakat jika ada } \\
\text { perselisihan }\end{array}$ & $\mathrm{X}_{2.7}$ & 74.545 \\
\hline $\begin{array}{l}\text { Estimasi biaya proyek } \\
\text { sudah tepat }\end{array}$ & $\mathrm{X}_{5.2}$ & 69.091 \\
\hline $\begin{array}{l}\text { Teknologi dijadikan alat } \\
\text { ukur } \\
\text { proyek }\end{array}$ & $\mathrm{X}_{4.3}$ & 68.485 \\
\hline 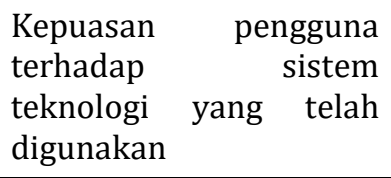 & $\mathrm{X}_{4.4}$ & 67.879 \\
\hline $\begin{array}{l}\text { Tingkat penggunaan } \\
\text { teknologi relatif tinggi }\end{array}$ & $\mathrm{X}_{4.2}$ & 67.273 \\
\hline $\begin{array}{l}\text { Dapat dengan tepat } \\
\text { mengelola anggaran } \\
\text { biaya proyek yang telah } \\
\text { direncanakan }\end{array}$ & $\mathrm{X}_{5.7}$ & 67.273 \\
\hline $\begin{array}{l}\text { Ketersediaan dan } \\
\text { ketepatan alokasi dana }\end{array}$ & $\mathrm{X}_{5.9}$ & 66.667 \\
\hline $\begin{array}{l}\text { Intensitas curah hujan } \\
\text { tinggi }\end{array}$ & $\mathrm{X}_{1.1}$ & 64.848 \\
\hline
\end{tabular}

\begin{tabular}{|c|c|c|}
\hline Faktor & Indikator & $\begin{array}{c}\text { Nilai } \\
\text { RII }\end{array}$ \\
\hline $\begin{array}{l}\text { Situasi sosial politik yang } \\
\text { kurang stabil }\end{array}$ & $\mathrm{X}_{3.2}$ & 64.242 \\
\hline Kenaikan harga BBM & $\mathrm{X}_{3.4}$ & 64.242 \\
\hline $\begin{array}{l}\text { Nilai tukar mata uang } \\
\text { yang semakin tinggi }\end{array}$ & $\mathrm{X}_{3.3}$ & 63.636 \\
\hline $\begin{array}{lr}\text { Adanya } & \text { kebijakan } \\
\text { moneter } & \text { yang } \\
\text { diperbaharui } & \\
\end{array}$ & $\mathrm{X}_{3.1}$ & 63.030 \\
\hline $\begin{array}{l}\text { Padatnya penduduk } \\
\text { yang bermukim di area } \\
\text { proyek }\end{array}$ & $\mathrm{X}_{2.2}$ & 62.424 \\
\hline $\begin{array}{l}\text { Kurangnya pemahaman } \\
\text { secara luas mengenai } \\
\text { ilmu teknologi yang } \\
\text { sudah berkembang }\end{array}$ & $\mathrm{X}_{4.6}$ & 62.424 \\
\hline $\begin{array}{l}\text { Inflasi dan suku bunga } \\
\text { tinggi }\end{array}$ & $\mathrm{X}_{5.1}$ & 62.424 \\
\hline $\begin{array}{l}\text { Kondisi lahan tanah yang } \\
\text { tidak terduga }\end{array}$ & $\mathrm{X}_{1.2}$ & 61.818 \\
\hline $\begin{array}{l}\text { Sistem regulasi } \\
\text { perpajakan yang kurang } \\
\text { efisien }\end{array}$ & $\mathrm{X}_{3.5}$ & 61.818 \\
\hline $\begin{array}{lrr}\text { Kondisi force } & \text { majeure } \\
\text { yang tidak } & \text { bisa } \\
\text { dikendalikan } & \\
\end{array}$ & $\mathrm{X}_{1.5}$ & 61.212 \\
\hline $\begin{array}{l}\text { Situasi dan kondisi di } \\
\text { sekitar proyek yang } \\
\text { mengganggu aktifitas } \\
\text { perkantoran }\end{array}$ & $\mathrm{X}_{2.6}$ & 61.212 \\
\hline $\begin{array}{l}\text { Tingkat lalu lintas yang } \\
\text { kurang memadai }\end{array}$ & $\mathrm{X}_{2.4}$ & 60.606 \\
\hline $\begin{array}{l}\text { Adanya keterlibatan } \\
\text { demonstrasi } \quad \text { akibat } \\
\text { sistem politik di negara } \\
\text { yang tidak bagus }\end{array}$ & $\mathrm{X}_{3.6}$ & 60.606 \\
\hline $\begin{array}{l}\text { Kegagalan dalam } \\
\text { penempatan tata letak } \\
\text { peralatan proyek }\end{array}$ & $\mathrm{X}_{1.8}$ & 60.000 \\
\hline $\begin{array}{lr}\text { Perhitungan } & \text { yang } \\
\text { kurang baik } & \text { dalam } \\
\text { rencana biaya } & \text { material } \\
\text { dan peralatan } & \end{array}$ & $\mathrm{X}_{5.6}$ & 60.000 \\
\hline $\begin{array}{l}\text { Manajemen } \\
\text { perencanaan keuangan } \\
\text { yang tidak baik }\end{array}$ & $\mathrm{X}_{5.4}$ & 58.788 \\
\hline
\end{tabular}




\begin{tabular}{|c|c|c|}
\hline Faktor & Indikator & $\begin{array}{c}\text { Nilai } \\
\text { RII }\end{array}$ \\
\hline $\begin{array}{lr}\text { Kerusakan } & \text { lahan } \\
\text { masyarakat } & \text { yang } \\
\text { berdekatan } & \end{array}$ & $\mathrm{X}_{2.5}$ & 58.182 \\
\hline $\begin{array}{l}\text { Keterlambatan } \\
\text { pembayaran termin dari } \\
\text { owner }\end{array}$ & $\mathrm{X}_{5.5}$ & 58.182 \\
\hline $\begin{array}{l}\text { Tingkat kebisingan } \\
\text { berlebihan }\end{array}$ & $\mathrm{X}_{1.6}$ & 57.576 \\
\hline $\begin{array}{l}\text { Kesulitan dalam } \\
\text { pembebasan lahan di } \\
\text { sekitar proyek }\end{array}$ & $\mathrm{X}_{2.1}$ & 57.576 \\
\hline $\begin{array}{l}\text { Pengajuan progres } \\
\text { kontraktor ke owner } \\
\text { yang kurang efisien dan } \\
\text { efektif }\end{array}$ & $\mathrm{X}_{5.8}$ & 57.576 \\
\hline $\begin{array}{l}\text { Kondisi modal kerja } \\
\text { penyedia jasa kurang } \\
\text { baik }\end{array}$ & $\mathrm{X}_{5.3}$ & 56.970 \\
\hline $\begin{array}{l}\text { Kondisi lingkungan kerja } \\
\text { yang buruk }\end{array}$ & $\mathrm{X}_{1.3}$ & 56.364 \\
\hline $\begin{array}{l}\text { Kerusakan sumber daya } \\
\text { alam sekitar seperti } \\
\text { tumbuhan atau hewan }\end{array}$ & $\mathrm{X}_{1.7}$ & 55.152 \\
\hline $\begin{array}{l}\text { Pencahayaan } \\
\text { kurang baik }\end{array}$ & $\mathrm{X}_{2.3}$ & 55.152 \\
\hline $\begin{array}{l}\text { Akses ke lokasi proyek } \\
\text { sangat sulit }\end{array}$ & $\mathrm{X}_{1.4}$ & 52.727 \\
\hline
\end{tabular}

Berdasarkan Tabel 9 didapatkan faktorfaktor eksternal yang menjadi penentu efektivitas pelaksanaan proyek melalui 10 peringkat teratas relative importance index (RII), sehingga didapatkan faktor-faktor eksternal seperti pada tabel 10 di bawah ini:

Tabel 10. Faktor Eksternal Efektivitas Proyek

\begin{tabular}{lcc}
\hline \multicolumn{1}{c}{ Faktor } & Indikator & $\begin{array}{c}\text { Nilai } \\
\text { RII }\end{array}$ \\
\hline $\begin{array}{l}\text { Penggunaan internet } \\
\text { untuk mencari sumber } \\
\text { informasi }\end{array}$ & $\mathrm{X}_{4.1}$ & 77.576 \\
\hline $\begin{array}{l}\text { Pemakaian media } e \text {-mail } \\
\text { sebagai alat komunikasi } \\
\text { surat menyurat }\end{array}$ & $\mathrm{X}_{4.5}$ & 75.152 \\
\hline
\end{tabular}

\begin{tabular}{|c|c|c|}
\hline Faktor & Indikator & $\begin{array}{c}\text { Nilai } \\
\text { RII }\end{array}$ \\
\hline $\begin{array}{lr}\text { Selalu menyelesaikan } \\
\text { masalah } & \text { dengan } \\
\text { masyarakat jika ada } \\
\text { perselisihan }\end{array}$ & $\mathrm{X}_{2.7}$ & 74.545 \\
\hline $\begin{array}{l}\text { Estimasi biaya proyek } \\
\text { sudah tepat }\end{array}$ & $\mathrm{X}_{5.2}$ & 69.091 \\
\hline $\begin{array}{l}\text { Teknologi } \\
\text { ukur } \\
\text { proyek }\end{array}$ & $\mathrm{X}_{4.3}$ & 68.485 \\
\hline 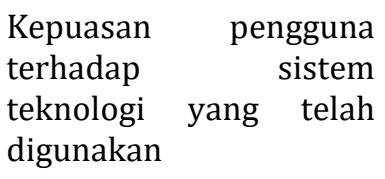 & $\mathrm{X}_{4.4}$ & 67.879 \\
\hline $\begin{array}{l}\text { Tingkat penggunaan } \\
\text { teknologi relatif tinggi }\end{array}$ & $\mathrm{X}_{4.2}$ & 67.273 \\
\hline $\begin{array}{l}\text { Dapat dengan tepat } \\
\text { mengelola anggaran } \\
\text { biaya proyek yang telah } \\
\text { direncanakan }\end{array}$ & $\mathrm{X}_{5.7}$ & 67.273 \\
\hline $\begin{array}{l}\text { Ketersediaan dan } \\
\text { ketepatan alokasi dana }\end{array}$ & $X_{5.9}$ & 66.667 \\
\hline $\begin{array}{l}\text { Intensitas curah hujan } \\
\text { tinggi }\end{array}$ & $\mathrm{X}_{1.1}$ & 64.848 \\
\hline
\end{tabular}

\section{Analisis relative importance index (RII)} berdasarkan faktor internal

Tabel 11. Perhitungan Pemeringkatan Relative Importance Index (RII) Faktor Internal

\begin{tabular}{lcc}
\hline \multicolumn{1}{c}{ Faktor } & Indikator & Nilai RII \\
\hline $\begin{array}{l}\text { Komitmen yang sudah } \\
\text { dibuat antara owner dan } \\
\text { kontraktor tepat waktu }\end{array}$ & $\mathrm{X}_{10.5}$ & 74.545 \\
\hline $\begin{array}{l}\text { Membuat hasil kerja } \\
\text { lebih berkualitas dan } \\
\text { produktivitas }\end{array}$ & $\mathrm{X}_{10.2}$ & 72.727 \\
\hline $\begin{array}{l}\text { Mampu bersama-sama } \\
\text { memecahkan konflik di } \\
\text { proyek }\end{array}$ & $\mathrm{X}_{9.6}$ & \\
\hline $\begin{array}{l}\text { Susunan organisasi yang } \\
\text { tepat dalam menangani } \\
\text { proyek }\end{array}$ & $\mathrm{X}_{8.1}$ & 70.515 \\
\hline $\begin{array}{l}\text { Mengkondisikan dan } \\
\text { mengontrol pelaksaan } \\
\text { proyek sehingga dapat } \\
\text { berjalan dengan baik }\end{array}$ & $\mathrm{X}_{8.9}$ & 70.909 \\
\hline
\end{tabular}




\begin{tabular}{|c|c|c|}
\hline Faktor & Indikator & Nilai RII \\
\hline $\begin{array}{l}\text { Metode pelaksanaan dari } \\
\text { setiap kegiatan proyek } \\
\text { dapat dijalankan dengan } \\
\text { efektif }\end{array}$ & $\mathrm{X}_{8.10}$ & 70.909 \\
\hline $\begin{array}{l}\text { Berusaha mencapai } \\
\text { kualitas produk untuk } \\
\text { hasil yang dicapai }\end{array}$ & $\mathrm{X}_{10.1}$ & 70.909 \\
\hline $\begin{array}{l}\text { Menetapkan anggota tim } \\
\text { proyek sesuai dengan } \\
\text { keahliannya }\end{array}$ & $\mathrm{X}_{8.6}$ & 70.303 \\
\hline $\begin{array}{lr}\text { Tujuan } & \text { teknis dari } \\
\text { proyek } & \text { konstruksi } \\
\text { tercapai } & \end{array}$ & $\mathrm{X}_{8.8}$ & 70.303 \\
\hline $\begin{array}{l}\text { Mampu menciptakan } \\
\text { semangat tim proyek } \\
\text { apabila ada perubahan }\end{array}$ & $\mathrm{X}_{9.4}$ & 70.303 \\
\hline $\begin{array}{l}\text { Sering terjadi kesalahan } \\
\text { dan perubahan desain }\end{array}$ & $\mathrm{X}_{8.2}$ & 69.091 \\
\hline $\begin{array}{l}\text { Menekan risiko yang } \\
\text { timbul sekecil mungkin }\end{array}$ & $\mathrm{X}_{6.1}$ & 68.485 \\
\hline $\begin{array}{lr}\text { Keterlambatan } & \text { proyek } \\
\text { membuat kurang } & \text { adanya } \\
\text { kepercayaan } & \text { untuk } \\
\text { keterlibatan } & \text { proyek } \\
\text { selanjutnya } & \end{array}$ & $\mathrm{X}_{10.3}$ & 67.273 \\
\hline $\begin{array}{l}\text { Kesadaran pemahaman } \\
\text { akan arti kesehatan dan } \\
\text { keselamatan kerja }\end{array}$ & $\mathrm{X}_{6.7}$ & 66.667 \\
\hline $\begin{array}{l}\text { Komposisi yang baik } \\
\text { dalam menempatkan } \\
\text { kelompok kerja seperti } \\
\text { tukang besi, tukang batu } \\
\text { dan lain-lain }\end{array}$ & $\mathrm{X}_{7.9}$ & 66.667 \\
\hline $\begin{array}{lr}\text { Pelatihan } & \text { dan } \\
\text { pengawasan } & \text { yang } \\
\text { kurang memadai } & \end{array}$ & $\mathrm{X}_{7.12}$ & 64.242 \\
\hline $\begin{array}{lr}\text { Mencegah } & \text { terjadinya } \\
\text { kesalahan } & \text { dalam } \\
\text { pelaksanaan } & \end{array}$ & $\mathrm{X}_{10.4}$ & 64.242 \\
\hline $\begin{array}{l}\text { Keterbatasan waktu } \\
\text { pelaksanaan dari awal } \\
\text { sampai berakhir nya } \\
\text { proyek }\end{array}$ & $\mathrm{X}_{7.10}$ & 63.636 \\
\hline $\begin{array}{l}\text { Mengontrol pekerjaan, } \\
\text { biaya, sumber daya dan } \\
\text { waktu dengan baik }\end{array}$ & $\mathrm{X}_{8.5}$ & 63.636 \\
\hline
\end{tabular}

\begin{tabular}{|c|c|c|}
\hline Faktor & Indikator & Nilai RII \\
\hline $\begin{array}{l}\text { Adanya perubahan } \\
\text { ruang lingkup yang } \\
\text { kurang baik }\end{array}$ & $\mathrm{X}_{8.7}$ & 63.636 \\
\hline Kenaikan harga material & $\mathrm{X}_{7.2}$ & 62.424 \\
\hline $\begin{array}{l}\text { Harga sewa peralatan } \\
\text { yang sangat mahal }\end{array}$ & $\mathrm{X}_{7.7}$ & 62.424 \\
\hline $\begin{array}{l}\text { Keterlambatan material } \\
\text { atau bahan pada saat } \\
\text { pelaksanaan }\end{array}$ & $\mathrm{X}_{7.3}$ & 61.818 \\
\hline $\begin{array}{l}\text { Perencanaan } \quad \text { dan } \\
\text { pelaksanaan } \\
\text { kurang baik }\end{array}$ & $\mathrm{X}_{9.3}$ & 61.818 \\
\hline $\begin{array}{l}\text { Kurangnya organisasi } \\
\text { yang kuat dalam tim } \\
\text { membuat hasil yang } \\
\text { dicapai kurang maksimal }\end{array}$ & $\mathrm{X}_{10.6}$ & 61.818 \\
\hline $\begin{array}{l}\text { Kekurangan tenaga kerja } \\
\text { saat pelaksanaan di } \\
\text { proyek }\end{array}$ & $\mathrm{X}_{7.8}$ & 61.212 \\
\hline $\begin{array}{l}\text { Upah tenaga kerja yang } \\
\text { tinggi }\end{array}$ & $\mathrm{X}_{7.5}$ & 60.606 \\
\hline $\begin{array}{l}\text { Kegagalan menggunakan } \\
\text { Alat Pelindung Diri } \\
\text { (APD) dengan benar }\end{array}$ & $\mathrm{X}_{6.5}$ & 60.000 \\
\hline $\begin{array}{l}\text { Tenaga kerja yang } \\
\text { lembur } \\
\text { menyebabkan efisiensi } \\
\text { dan efektivitas dalam } \\
\text { bekerja }\end{array}$ & $\mathrm{X}_{7.4}$ & 60.000 \\
\hline $\begin{array}{l}\text { Tempat penyimpanan } \\
\text { material bahan yang } \\
\text { kurang memadai }\end{array}$ & $\mathrm{X}_{7.13}$ & 60.000 \\
\hline $\begin{array}{l}\text { Kurangnya disiplin } \\
\text { dalam menjalankan } \\
\text { standar SOP }\end{array}$ & $\mathrm{X}_{8.3}$ & 60.000 \\
\hline $\begin{array}{l}\text { Membuat tim proyek } \\
\text { menjadi kreatif dan } \\
\text { inovatif }\end{array}$ & $\mathrm{X}_{9.2}$ & 60.000 \\
\hline $\begin{array}{l}\text { Safety factor pada } \\
\text { pelaksanaan } \\
\text { sangat kurang }\end{array}$ & $\mathrm{X}_{6.4}$ & 57.576 \\
\hline $\begin{array}{l}\text { Efisiensi biaya, sumber } \\
\text { daya dan waktu dengan } \\
\text { baik }\end{array}$ & $\mathrm{X}_{8.4}$ & 57.576 \\
\hline $\begin{array}{lr}\text { Manajemen } & \text { dan } \\
\text { pengawasan } & \text { proyek } \\
\text { yang buruk } & \end{array}$ & $\mathrm{X}_{9.5}$ & 56.970 \\
\hline
\end{tabular}




\begin{tabular}{lcc}
\hline \multicolumn{1}{c}{ Faktor } & Indikator & Nilai RII \\
\hline $\begin{array}{l}\text { Kontrol kualitas material } \\
\text { yang buruk }\end{array}$ & $\mathrm{X}_{7.6}$ & 56.970 \\
\hline $\begin{array}{l}\text { Tenaga kerja tidak } \\
\text { memiliki keterampilan } \\
\text { dan keahlian di } \\
\text { bidangnya }\end{array}$ & $\mathrm{X}_{7.1}$ & 56.364 \\
\hline $\begin{array}{l}\text { Sering tidak mengikuti } \\
\text { Safety Talk harian }\end{array}$ & $\mathrm{X}_{6.6}$ & 55.758 \\
\hline $\begin{array}{l}\text { Komunikasi dan } \\
\text { koordinasi proyek tidak } \\
\text { berjalan dengan baik }\end{array}$ & $\mathrm{X}_{9.1}$ & 55.758 \\
\hline $\begin{array}{l}\text { Tidak adanya tolong- } \\
\text { menolong dalam hal sub }\end{array}$ & $\mathrm{X}_{9.7}$ & \\
item pekerjaan & & \\
\hline $\begin{array}{l}\text { Kurangnya penyediaan } \\
\text { Alat Pelindung Diri } \\
\text { (APD) di proyek }\end{array}$ & $\mathrm{X}_{6.8}$ & 55.758 \\
\hline $\begin{array}{l}\text { Lemahnya respon jika } \\
\text { terjadi kecelakaan kerja }\end{array}$ & $\mathrm{X}_{6.2}$ & 54.545 \\
\hline $\begin{array}{l}\text { Pemilihan metode } \\
\text { pelaksanaan konstruksi } \\
\text { tidak diperhitungkan } \\
\text { oleh aspek risiko }\end{array}$ & $\mathrm{X}_{6.3}$ & 54.545 \\
\hline $\begin{array}{l}\text { Tidak adanya } \\
\text { ketersediaan } \\
\text { material yang akan } \\
\text { digunakan pada saat } \\
\text { pelaksanaan proyek }\end{array}$ & $\mathrm{X}_{7.11}$ & \\
\hline & & \\
\hline
\end{tabular}

Berdasarkan Tabel 11 didapatkan faktorfaktor eksternal yang menjadi penentu efektivitas pelaksanaan proyek melalui 10 peringkat teratas relative importance index (RII), sehingga didapatkan faktor-faktor internal seperti pada tabel 10 di bawah ini:

Tabel 12. Faktor Internal Efektivitas Proyek

\begin{tabular}{lcc}
\hline \multicolumn{1}{c}{ Faktor } & Indikator & Nilai RII \\
\hline $\begin{array}{l}\text { Komitmen yang sudah } \\
\text { dibuat antara owner dan } \\
\text { kontraktor tepat waktu }\end{array}$ & $\mathrm{X}_{10.5}$ & 74.545 \\
\hline $\begin{array}{l}\text { Membuat hasil kerja } \\
\text { lebih berkualitas dan } \\
\text { produktivitas }\end{array}$ & $\mathrm{X}_{10.2}$ & 72.727 \\
$\begin{array}{l}\text { Mampu bersama-sama } \\
\text { memecahkan konflik di } \\
\text { proyek }\end{array}$ & $\mathrm{X}_{9.6}$ & 71.515 \\
\hline
\end{tabular}

\begin{tabular}{lcc}
\hline \multicolumn{1}{c}{ Faktor } & Indikator & Nilai RII \\
\hline $\begin{array}{l}\text { Susunan organisasi yang } \\
\text { tepat dalam menangani } \\
\text { proyek }\end{array}$ & $\mathrm{X}_{8.1}$ & 70.909 \\
\hline $\begin{array}{l}\text { Mengkondisikan dan } \\
\text { mengontrol pelaksaan } \\
\text { proyek sehingga dapat }\end{array}$ & $\mathrm{X}_{8.9}$ & 70.909 \\
berjalan dengan baik & & \\
\hline $\begin{array}{l}\text { Metode pelaksanaan dari } \\
\text { setiap kegiatan proyek } \\
\text { dapat dijalankan dengan } \\
\text { efektif }\end{array}$ & $\mathrm{X}_{8.10}$ & 70.909 \\
\hline $\begin{array}{l}\text { Berusaha mencapai } \\
\text { kualitas produk untuk }\end{array}$ & $\mathrm{X}_{10.1}$ & \\
hasil yang dicapai & & \\
\hline $\begin{array}{l}\text { Menetapkan anggota tim } \\
\text { proyek sesuai dengan } \\
\text { keahliannya }\end{array}$ & $\mathrm{X}_{8.6}$ & 70.909 \\
\hline $\begin{array}{l}\text { Tujuan teknis dari } \\
\text { proyek konstruksi } \\
\text { tercapai }\end{array}$ & $\mathrm{X}_{8.8}$ & 70.303 \\
\hline $\begin{array}{l}\text { Mampu menciptakan } \\
\text { semangat tim proyek } \\
\text { apabila ada perubahan }\end{array}$ & $\mathrm{X}_{9.4}$ & \\
\hline
\end{tabular}

\section{PEMBAHASAN HASIL PENELITIAN}

Berdasarkan hasil pengolahan data yang telah teridentifikasi dari peringkat faktor eksternal dan faktor internal dalam efektivitas pelaksanaan proyek pembangunan hotel Ashley Sabang, diambil poin terpenting dari hasil pengolahan yaitu sebagai berikut:

1. Internet menjadi sumber informasi yang sangat luas dan meliputi berbagai hal yang mencakup pada kegiatan proyek baik dari hulu sampai kepada hilir. Para kontraktor dapat mengakses internet untuk mendapat kan informasi mengenai segala prosedur dan pelaksanaan hingga tercapainya tujuan proyek sesuai dengan kriteria owner. Informasi yang ada pada internet tersebut juga dapat digunakan oleh owner untuk dasar informasi yang memang harus di ketahui sebagai bentuk pengendalian mutu terhadap proyek yang akan dilaksanakan. Informasi yang sudah dimiliki oleh 
owner dan kontraktor tersebut menjadi kan sebuah komitmen, karna kedua belah pihak sudah memiliki informasi yang luas terhadap proyek yang akan dilaksanakan. Tujuan dari komitmen tersebut adalah tepat waktu, banyak nya informasi yang sudah diperoleh kedua belah pihak akan menjadikan pengendalian kualitas pada proyek, alhasil tujuan proyek akan tercapai sesuai dengan komitmen yang dilakukan oleh owner dan kontraktor.

2. Keberhasilan sebuah proyek berdasarkan karakteristik yang dibutuhkan oleh pemilik proyek atau owner merupakan tujuan dari kualitas proyek. Pengecekan dan pengkajian didalam proyek dilakukan untuk mengetahui dan meyakini bahwa kriteria, spesifikasi, dan standar yang ditentukan telah terpenuhi. Penggunaan media email sebagai alat komunikasi surat menyurat menjadikan kegiatan rutin yang bersifat aktual dan penanggung jawab di proyek akan melakukan pengecekan terhadap kriteria, spesifikasi dan standar yang telah ditentukan, jika semua sudah terpenuhi akan dilakukan laporan langsung dari manager proyek ke pemilik proyek. Jika pemakaian media email dilakukan pada setiap waktu, tingkat produktivitas akan meningkat karena informasi yang didapat secara aktual, dan dapat dilakukan pengambilan keputusan secara tepat. Para penanggung jawab proyek juga mendapatkan informasi aktual apakah kualitas yang ada di proyek sesuai dengan kriteria yang dibutuhkan.

3. Banyaknya permasalahan di proyek yang menyebabkan konflik dapat diidentifikasi dari potensi yang dapat penghambat jalannya penyelenggaraan proyek konstruksi. Setiap individu dalam suatu proyek memiliki tujuan masing-masing, dimana pemimpin proyek mempunyai peranan penting untuk memberikan perhatian penuh atas keinginan individu dari organisasi proyek. Bila konflik teratasi dengan baik, artinya organisasi dalam suatu proyek merupakan sarana atau wadah perubahan yang positif dalam memecahkan suatu masalah. Dengan motivasi yang tinggi dan sikap solidaritas dari seorang pemimpin dapat menciptakan sumber daya manusia yang loyal akan pekerjaannya dalam menangani suatu proyek. Dalam memimpin suatu proyek, project manager biasanya mempengaruhi dan mengarahkan tim anggota nya untuk bekerja sama agar tujuan yang telah ditentukan tercapai. Dengan menumbuhkan motivasi yang tinggi bagi sesama pekerja akan meningkatkan saling menghargai satu sama lain. Jika seorang pemimpin dapat menciptakan situasi kondusif dan menumbuhkan rasa toleransi yang tinggi pada lingkungan dimana ia bekerja, dalam menangani suatu konflik pemimpin dapat mengajak seluruh anggota tim nya bersama-sama menyelesaikan perselisihan yang terjadi baik di dalam atau lingkungan proyek dengan menerapkan norma-norma yang telah diterapkan.

\section{KESIMPULAN}

Dari hasil analisis data dari penelitian mengenai analisis faktor-faktor eksternal dan internal dalam efektivitas pelaksanaan proyek pembangunan hotel Ashley Sabang yang telah dilakukan, maka dapat diambil kesimpulan sebagai berikut:

1. Terdapat 10 peringkat teratas faktor eksternal yang mempengaruhi efektivitas pelaksanaan proyek yaitu; penggunaan internet untuk mencari sumber informasi, pemakaian media $e$ mail sebagai alat komunikasi surat menyurat, selalu menyelesaikan masalah dengan masyarakat jika ada perselisihan, estimasi biaya proyek sudah tepat, teknologi dijadikan alat ukur keberhasilan proyek, kepuasan pengguna terhadap sistem teknologi yang telah digunakan, tingkat 
penggunaan teknologi relatif tinggi, dapat dengan tepat mengelola anggaran biaya proyek yang telah direncanakan, ketersediaan dan ketepatan alokasi dana dan Intensitas curah hujan tinggi. Sedangkan10 peringkat teratas faktor internal yang mempengaruhi efektivitas pelaksanaan proyek yaitu; komitmen yang sudah dibuat antara owner dan kontraktor tepat waktu, membuat hasil kerja lebih berkualitas dan produktivitas, mampu bersama-sama memecahkan konflik di proyek, Susunan organisasi yang tepat dalam menangani proyek, mengkondisikan dan mengontrol pelaksanaan proyek sehingga dapat berjalan dengan baik, metode pelaksanaan dari setiap kegiatan proyek dapat dijalankan dengan efektif, berusaha mencapai kualitas produk untuk hasil yang dicapai, menetapkan anggota tim proyek sesuai dengan keahliannya, tujuan teknis dari proyek konstruksi tercapai dan mampu menciptakan semangat tim proyek apabila ada perubahan.

2. Terdapat beberapa kategori faktorfaktor eksternal dalam efektivitas pelaksanaan proyek pembangunan hotel Ashley Sabang adalah faktor lingkungan (alam, cuaca), faktor sosial (adat, budaya serta kondisi masyarakat), faktor politik dan hukum (kebijakan pemerintah), faktor teknologi, dan faktor ekonomi. Sedangkan faktor-faktor internal dalam efektivitas pelaksanaan proyek pembangunan hotel Ashley Sabang adalah; faktor manajemen risiko (K3), faktor sumber daya, faktor manajemen proyek, faktor organisasi dan faktor manajemen kualitas.

3. Berdasarkan hasil penelitian dan pembahasan dengan nilai RII tertinggi diatas 71,515 yang telah dilakukan, didapatkan pula faktor eksternal penentu efektivitas pelaksanaan proyek pembangunan hotel Ashley Sabang yaitu; penggunaan internet untuk mencari sumber informasi, pemakaian media $e$ mail sebagai alat komunikasi surat menyurat, dan selalu menyelesaikan masalah dengan masyarakat jika ada perselisihan. Sedangkan faktor internal penentu efektivitas pelaksanaan proyek pembangunan hotel Ashley Sabang yaitu; komitmen yang sudah dibuat antara owner dan kontraktor tepat waktu, membuat hasil kerja lebih berkualitas dan produktivitas, dan mampu bersamasama memecahkan konflik di proyek.

\section{DAFTAR PUSTAKA}

[1] Arindya, Radita. (2019). Efektivitas Organisasi Tata Kelola Minyak dan Gas Bumi. Media Sahabat: Surabaya.

[2] Barry, Donald S., and Paulson. (1998). Manajemen Proyek Profesional. Pradyna Paramita: Jakarta.

[3] Dipohusodo, Istimawan. (1996). Manajemen Proyek \& Konstruksi Jilid 2. Kansius: Yogyakarta.

[4] Endra, Febri. (2017). Pengantar Metodologi Penelitian (Statistika Praktis). Zifatama Jawara: Sidoarjo.

[5] Ervianto, W.I. (2005). Manajemen Proyek Konstruksi (Edisi Revisi). Andi: Yogyakarta.

[6] Ghozali, I. (2011). Aplikasi Analisis Multivariate Dengan Program IBM SPSS 19 (Edisi Kelima). Universitas Diponegoro: Semarang.

[7] Hardcastle, C., Edwards, P.J., Akintoye, A.Q., \& Li, B. (2002). Critical Success Factors For PPP/PFI Projects in The UK Construction Industry: A Factor Analysis Approach. Working Paper.

[8] Hardjomuljadi, S., dan Wahyudi, N. (2009). Kendala Serah Terima Proyek Konstruksi Antara DitJen Cipta Karya Dengan Pemerintah Daerah. Universitas Katolik Parahyangan: Bandung.

[9] Hwang, Bon-Gang., Lim, E-Sin Janicia. (2013). Critical Success Factors for Key Project Players and Objectives in the Singapore. Journal ASCE of Construction Engineering and 
Management. Singapore: Singapore University.

[10] Laturpeirissa, Josefine Ernetine. (2016). Metode Perencanaan Evaluasi dan Pengendalian Pelaksanaan Proyek Konstruksi. Andi: Yogyakarta.

[11] Sitanggang, Nathanael., Simarmata, Janner., dan Luthan, Putri. Lynna. (2019). Pengantar Konsep Manajemen Proyek untuk Teknik. Yayasan Kita Menulis: Sumatera Utara.

[12] Soeharto, I. (1995). Manajemen Proyek: Dari Konseptual Sampai Operasional. Erlangga: Jakarta.

[13] Sugiyono. (2012). Metode Penelitian Pendidikan. Alfabeta: Bandung.

[14] Trianto (2011). Mendesain Model Pembelajaran Inovatif-Progresif. Kencana Prenada Media Group: Jakarta.

[15] Trition, P.B. (2008), SPSS 13.0 Terapan. Penerbit Andi: Yogyakarta.

[16] Widiansanti, Irika., dan Lenggogeni. (2013). Manajemen Konstruksi. PT Remaja Rosdakarya: Bandung. 
